\title{
Can producer currency pricing models generate volatile real exchange rates?
}

\author{
Laura Povoledo \\ University of Reading*
}

March 2010

\begin{abstract}
If the elasticities of substitution between traded and nontraded and between Home and Foreign traded goods are sufficiently low, then the real exchange rate generated by a model with full producer currency pricing is as volatile as in the data.
\end{abstract}

JEL classification: F41; E32

Keywords: Real exchange rate volatility; Producer Currency Pricing; Elasticity of substitution; New Open-Economy Macroeconomics.

${ }^{*}$ Department of Economics, University of Reading, PO Box 218, Whiteknights, Reading RG6 6AA (UK). Present address: University of the West of England, Coldharbour Lane, Bristol BS16 1QY (UK). Tel: 004411732 83454. Email: Laura.Povoledo@uwe.ac.uk. 


\section{Introduction}

The high volatility of the real exchange rate is one of the most important stylized facts in international macroeconomics. In their seminal work, Chari et al. (2002) show that it is possible to reproduce quantitatively the empirical volatility of the real exchange rate in a dynamic stochastic general equilibrium model with sticky prices, provided certain conditions on preferences are satisfied and prices are held fixed for at least one year.

Chari et al. make use of the assumption of full local currency pricing (LCP). Under this assumption, fluctuations in the real exchange rate are primarily driven by deviations from the law of one price. Conversely, under the alternative assumption that all prices are set in the currency of the producer $(\mathrm{PCP})$, arbitrage equalises the price of traded goods, thus fluctuations in the real exchange rate are driven by fluctuations in the relative price of nontraded to traded goods.

Recently, Betts and Kehoe (2006) have challenged the view that the relative price of nontraded goods does not matter for real exchange rate fluctuations. They show that in some cases (depending on the choice of price series used to measure relative prices and on the choice of trade partner), there is a strong relationship between the United States' bilateral real exchange rate and the associated bilateral relative price of nontraded to traded goods. Thus, the data do not seem to suggest that the PCP assumption needs to be abandoned completely.

This paper investigates quantitatively a simple yet effective way to generate high real exchange rate volatility with full PCP. By choosing low values for two elasticities of substitution (between traded and nontraded and between Home and Foreign traded goods) it is possible to obtain highly volatile real exchange rates in a model with full PCP. Consequently, we can infer that relying exclusively on LCP to match the volatility of the real exchange rate might lead a researcher to choose too high elasticities. ${ }^{1}$

\section{The model}

The model is akin to the PCP model of Obstfeld and Rogoff (1995), but it also includes several features that have been introduced more recently. Price rigidity is modelled à la Calvo (1983), and a small cost of holding bonds ensures that the model is stationary. Moreover, the calibrated model includes the features that, according to Chari et al. (2002), are crucial for generating high real exchange rate volatility: separable preferences, high risk aversion, and price-stickiness of at least one year.

The world economy consists of two countries, named Home and Foreign, each of them producing both traded and non-traded goods. In each country and

\footnotetext{
${ }^{1}$ Obstfeld and Rogoff (2005) review the empirical literature and find that the range of values for the two substitution elasticities is quite large. They also report that some empirical studies have suggested values considerably lower than one.
} 
sector there exists a continuum of monopolistic firms, each of them producing a single differentiated good. The firms and the goods they produce are indexed by $f_{T H} \in[0,1]$ for the Home traded sector and $f_{N} \in[0,1]$ for the Home nontraded sector. Differentiated goods are imperfect substitutes in consumption.

The Home and Foreign countries are assumed to be symmetric, so only the equations describing the Home country will be presented here.

\subsection{Households}

The utility of the representative household in the Home country is given by:

$$
U_{0}=E_{0} \sum_{t=0}^{\infty} \beta^{t}\left[\frac{C_{t}^{1-\sigma}-1}{1-\sigma}+\frac{\chi}{1-\epsilon}\left(\frac{M_{t}}{P_{t}}\right)^{1-\epsilon}+\kappa \cdot \frac{\left(1-h_{T H, t}-h_{N, t}\right)^{1-\omega}}{1-\omega}\right],
$$

the variable $C$ is an aggregate consumption basket having price $P, M$ are nominal money balances, and $h_{T H}=\int_{0}^{1} h_{T H}\left(f_{T H}\right) d f_{T H}$ and $h_{N}=\int_{0}^{1} h_{N}\left(f_{N}\right) d f_{N}$ are total hours supplied by the household to the traded and the non-traded sectors respectively.

Preferences over traded and non-traded goods, and over Home and Foreignproduced traded goods, are described by CES aggregators:

$$
\begin{gathered}
C_{t}=\left[(1-\gamma)^{\frac{1}{\phi}}\left(C_{T, t}\right)^{\frac{\phi-1}{\phi}}+\gamma^{\frac{1}{\phi}}\left(C_{N, t}\right)^{\frac{\phi-1}{\phi}}\right]^{\frac{\phi}{\phi-1}}, \\
C_{T, t}=\left[(1-\delta)^{\frac{1}{\theta}}\left(C_{T H, t}\right)^{\frac{\theta-1}{\theta}}+\delta^{\frac{1}{\theta}}\left(C_{T F, t}\right)^{\frac{\theta-1}{\theta}}\right]^{\frac{\theta}{\theta-1}} .
\end{gathered}
$$

The variables $C_{N}, C_{T H}$ and $C_{T F}$ are themselves CES aggregators of differentiated varieties, with the same elasticity of substitution $\eta$. The law of one price holds for differentiated traded goods varieties. The price indices (in Home currency) $P, P_{T}, P_{N}$, and $P_{T H}$, and the Foreign price $P_{T F}^{*}$ (in Foreign currency) are defined as the minimal expenditure needed to buy one unit of the corresponding consumption aggregator.

The household's period- $t$ budget constraint is given by:

$$
\begin{aligned}
B_{t} P_{T, t} & +\frac{1}{2} \frac{\nu}{C_{0}} B_{t}^{2} P_{T, t}+M_{t} \leq\left(1+r_{t-1}\right) B_{t-1} P_{T, t}+M_{t-1}+W_{t} h_{T H, t}+W_{t} h_{N, t}+ \\
& +T R_{t}+\int_{0}^{1} \Pi_{T H, t}\left(f_{T H}\right) d f_{T H}+\int_{0}^{1} \Pi_{N, t}\left(f_{N}\right) d f_{N}+R_{t}-P_{t} C_{t}
\end{aligned}
$$

The variable $B$ denotes an internationally traded bond, denominated in units of the Home traded consumption index. Similarly to Benigno (2009), the household must pay a cost for holding or issuing bonds. I assume that the cost is given by a quadratic function, ${ }^{2}$ governed by the positive parameter $\nu$, and that

\footnotetext{
${ }^{2} C_{0}$ denotes the steady-state value of consumption.
} 
it is reimbursed to the household in the form of lump-sum transfers $R$. The variable $r$ is the real interest rate, $W$ is the wage rate, the same in both sectors, and $T R$ are transfers from the government. Finally, $\Pi_{T H}\left(f_{T H}\right)$ and $\Pi_{N}\left(f_{N}\right)$ are the profits from the ownership of firms producing traded and non-traded goods respectively.

\subsection{Government and firms}

The government runs a balanced budget in each period: $M_{t}-M_{t-1}=T R_{t}$.

The production function of a traded sector firm is given by:

$$
y_{T H, t}\left(f_{T H}\right)=z_{T H, t} \cdot h_{T H, t}\left(f_{T H}\right)
$$

where $y_{T H, t}\left(f_{T H}\right)$ is the demand for variety $f_{T H}$, and $z_{T H}$ represents exogenous technology. The production functions in the other sectors are analogous.

Fluctuations are caused by shocks to the exogenous, zero-mean AR(1) processes which govern technology and the growth rates of nominal money in both countries.

\section{Solution and calibration}

The model is log-linearised around a deterministic steady state and solved numerically.

I consider a benchmark parametrization, summarised by Table 1, and then conduct sensitivity checks. ${ }^{3}$

Table 1 approximately here

The parameter $\sigma$ is the same as in Chari et al. (2002). ${ }^{4}$ Given $\sigma, \epsilon$ is chosen so that the consumption elasticity of money demand is equal to 1 , as in Chari et al..$^{5}$ Starting from the assumption that in the steady state the fraction of time spent working is equal to $0.31,{ }^{6}$ the parameter $\omega$ is then calibrated so that in the steady state the Frisch elasticity of labour supply ${ }^{7}$ is equal to 1.

The parameters describing the exogenous processes are taken from Chari et al., with two exceptions. The variance of the money shocks is chosen so that, when $\phi$ and $\theta$ are equal to one (an intermediate case), the standard deviation of

\footnotetext{
${ }^{3}$ The parameters and functional forms describing the Home and Foreign economies are assumed to be the same, but the weight assigned to Home-produced goods in the Foreign traded consumption basket is equal to $1-\delta$, to reflect the same degree of home-bias in both countries.

${ }^{4}$ The calibration of $\chi$ is irrelevant for the log-linearised solution of the model.

${ }^{5}$ Sensitivity checks show that the value of $\varepsilon$ has a very small impact on the volatility of the real exchange rate.

${ }^{6}$ The parameter $\kappa$ can be calibrated so that the steady state of the model possesses this property.

${ }^{7}$ The Frisch elasticity of labour supply in the steady state is equal to $\frac{1}{\omega} \frac{1-0.31}{0.31}$.
} 
output in the model is equal to $1.82 \%$, the same value as in Chari et al. ${ }^{8}$ The AR coefficients of the nontraded technology processes are taken from Povoledo (2012) and the standard deviation of the shocks is about half the standard deviation of the traded sector shocks.

\section{Results}

The real exchange rate is defined as the ratio of Foreign prices over Home prices, expressed in the same currency:

$$
R E R_{t} \equiv \frac{e_{t} \cdot P_{t}^{*}}{P_{t}}
$$

where $e$ is the nominal exchange rate. An increase (fall) in this quantity is a "depreciation" ("appreciation").

Figures 1 and 2 show the responses of $R E R$ to the shocks. The benchmark parametrisation is held constant and only the elasticities $\theta$ and $\phi$ vary between the two figures. The benchmark parametrisation is symmetrical and so are the responses to the Home and Foreign shocks.

Figures 1 and 2 approximately here

Consider, for example, a positive Home monetary shock. Its direct effect on (6) is the nominal depreciation of the Home currency, which in turn induces two sorts of expenditure-switching effects. First, the nominal depreciation increases the competitiveness of Home traded goods relative to Foreign traded goods. Secondly, since the price of imports $e \cdot P_{T F}^{*}$ increases, the nominal depreciation decreases the relative price of nontraded goods, $P_{N} / P_{T}$, in the Home country. Hence, international demand is switching away from Foreign traded goods, and Home domestic demand is switching away from the bundle of all traded goods. To achieve equilibrium in all markets, the former expenditure-switching effect is absorbed by a fall ${ }^{9}$ in $P_{T F}^{*}$, the latter effect by an increase in $P_{N}$. As a result, the Home CPI $P$ increases and the Foreign CPI $P^{*}$ decreases, moderating the response of $R E R$ to the shock. With low $\theta$ and $\phi$, both expenditure-switching effects are more modest and the response of the real exchange rate to monetary shocks is sensibly magnified. ${ }^{10}$ Low values for $\theta$ and $\phi$ also magnify the response of the real exchange rate to technology shocks.

\section{Figure 3 approximately here}

\footnotetext{
${ }^{8}$ The ratio of the standard deviation of the real exchange rate divided by the standard deviation of GDP is almost unaffected by the size of the variance of the money shocks, as shown by sensitivity checks.

${ }^{9}$ Meanwhile, in the Foreign country the nominal depreciation decreases the cost of imports and reduces the attractiveness of nontraded goods, so Foreign nontraded goods prices fall too.

${ }^{10}$ This occurs also because low elasticities tend to increase the response of the nominal exchange rate after a monetary shock.
} 
Figure 3 illustrates the quantitative impact of both elasticities on the standard deviation of the real exchange rate over the standard deviation of output. The empirical estimates of this ratio vary in the literature: Chari et al. (2002) consider a value of 4.36, but Corsetti et al. (2008) report a value of 3.25 (US data). Nonetheless, both estimates can be successfully replicated by a PCP model if the two elasticities $\theta$ and $\phi$ are set at a sufficiently low level. For example, with both elasticities approximately equal to 0.58 the standard deviation of the real exchange rate in this model is equal to Chari et al.'s estimated value. Notice that with $\theta=1.5$, as in Chari et al., not even Corsetti et al.'s lower estimate can be replicated by the model.

Finally, sensitivity checks ${ }^{11}$ show that the negative slope of the isoquants in Figure 3 is robust to changes in the other parameter values. Hence, both elasticities affect the volatility of the real exchange rate in all departures from the benchmark parametrisation.

${ }^{11}$ Available on request. 


\section{References}

Benigno, P., 2009. Price Stability with Imperfect Financial Integration. Journal of Money, Credit and Banking 41, 121-149.

Betts, C. M., Kehoe T. J., 2006. U.S. real exchange rate fluctuations and relative price fluctuations. Journal of Monetary Economics 53, 1297-1326.

Calvo, G. A., 1983. Staggered Prices in a Utility-Maximizing Framework. Journal of Monetary Economics 12, 383-398.

Chari, V. V., Kehoe P. J., McGrattan E. R., 2002. Can Sticky Price Models Generate Volatile and Persistent Real Exchange Rates? Review of Economic Studies 69, 533-63.

Corsetti, G., Dedola L., Leduc S., 2008. High Exchange-Rate Volatility and Low Pass-Through. Journal of Monetary Economics 55, 1113-1128.

Obstfeld, M., Rogoff K., 2005. Global Current Account Imbalances and Exchange Rate Adjustments. Brookings Papers on Economic Activity, Economic Studies Program, The Brookings Institution, vol. 36(1), 67-146.

Obstfeld, M., Rogoff K., 1995. Exchange Rate Dynamics Redux. Journal of Political Economy 103, 624-660.

Povoledo, L., 2012. A Note on The Volatility of the Tradeable and Nontradeable Sectors. Macroeconomic Dynamics, in press. 
Table 1: Home and Foreign Parametrization

\begin{tabular}{llc}
\hline \hline$\beta$ & Discount factor & 0.99 \\
$\sigma$ & Risk aversion for consumption & 5 \\
$\epsilon$ & Elasticity of marginal utility of real money balances & 5 \\
$\omega$ & Elasticity of marginal utility of leisure & 2.226 \\
$\gamma$ & Weight of nontraded goods in total consumption & 0.70 \\
$\delta$ & Weight of Foreign goods in Home traded consumption & 0.30 \\
& $(1-\delta$ is the weight of Home goods in Foreign traded consumption $)$ \\
$\nu$ & Intermediation cost & 0.0005 \\
$\varphi$ & Probability of not changing prices & 0.75 \\
$\eta$ & Elasticity of substitution among differentiated goods & 7.88 \\
\hline
\end{tabular}

Exogenous AR(1) processes:

Money growth: $\rho_{\mu}=\rho_{\mu^{*}}=0.68, \operatorname{var}\left(\varepsilon_{\mu}\right)=\operatorname{var}\left(\varepsilon_{\mu^{*}}\right)=(0.0209)^{2}$,

Traded goods technology: $\rho_{z_{T H}}=\rho_{z_{T F}^{*}}=0.95, \operatorname{var}\left(\varepsilon_{z_{T H}}\right)=$

$$
\operatorname{var}\left(\varepsilon_{z_{T F}^{*}}\right)=(0.007)^{2}
$$

Nontraded goods technology: $\rho_{z_{N}}=\rho_{z_{N}^{*}}=0.80, \operatorname{var}\left(\varepsilon_{z_{N}}\right)=$

$$
\operatorname{var}\left(\varepsilon_{z_{N}^{*}}\right)=(0.003)^{2}
$$


Figure 1: Impulse responses of the real exchange rate with $\phi=\theta=2$

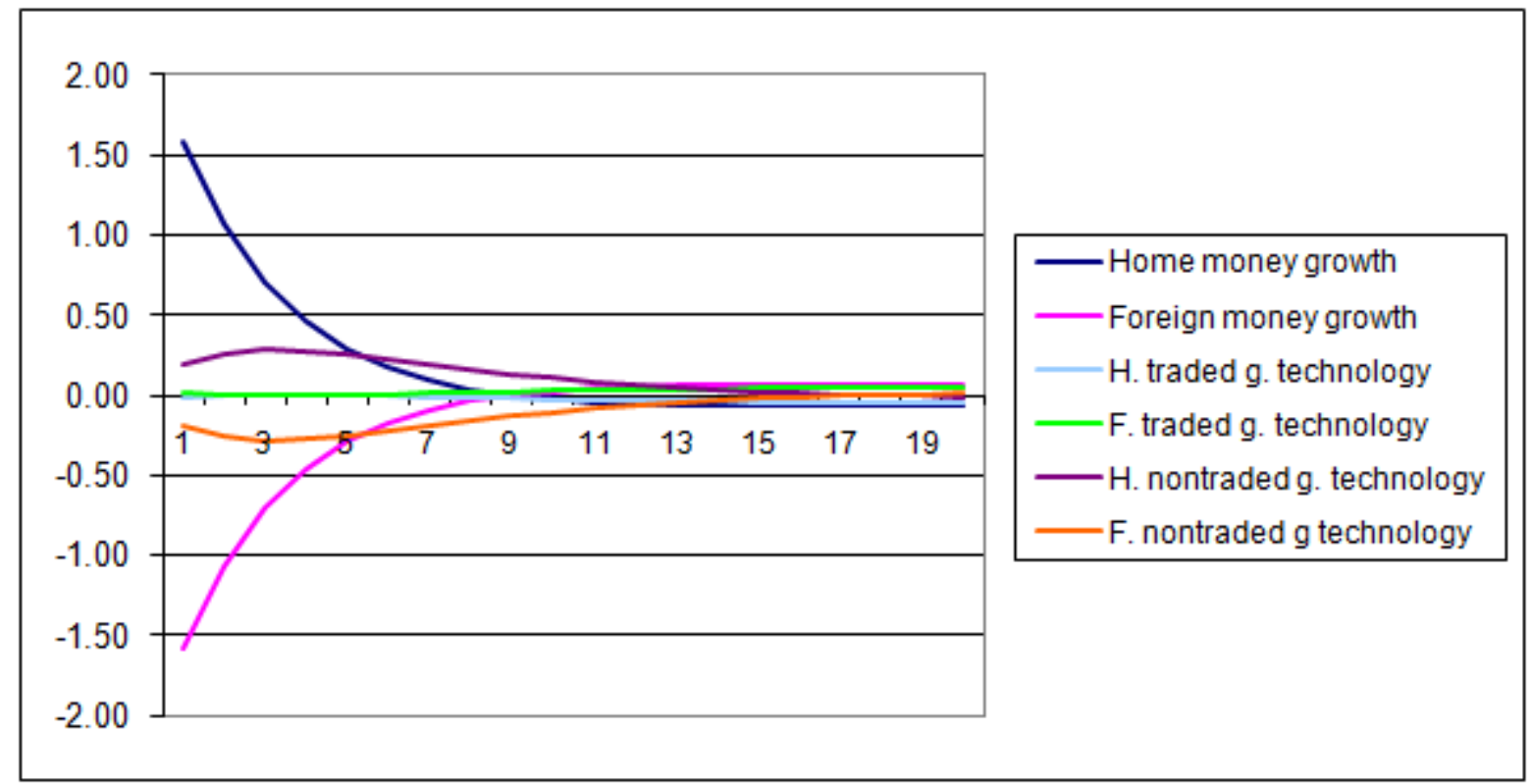

Figure 2: Impulse responses of the real exchange rate with $\phi=\theta=0.6$

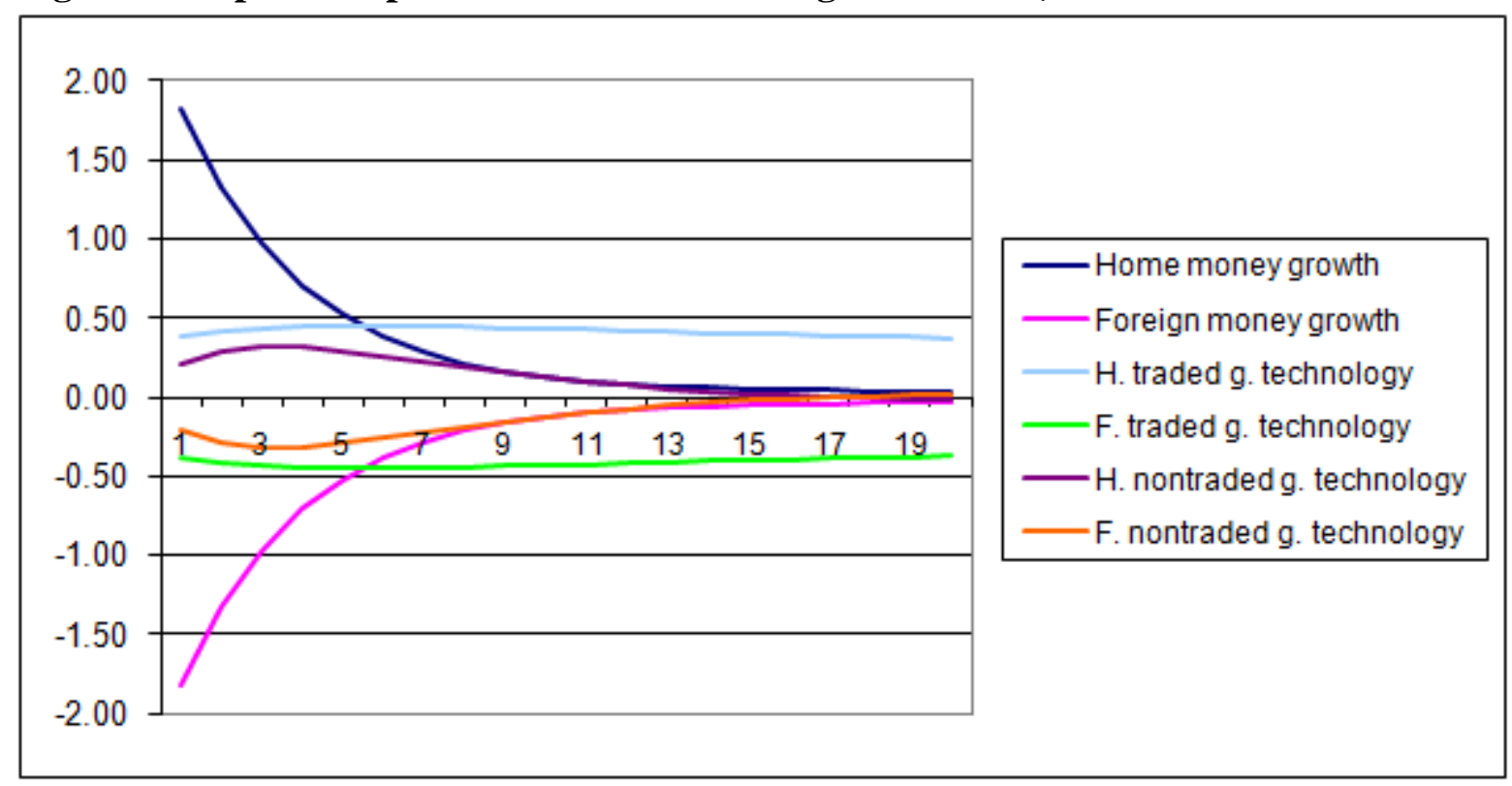

NOTE: Time is in quarters. 
Figure 3: Standard deviation of the real exchange rate (relative to GDP) as a function of $\phi$ and $\theta$

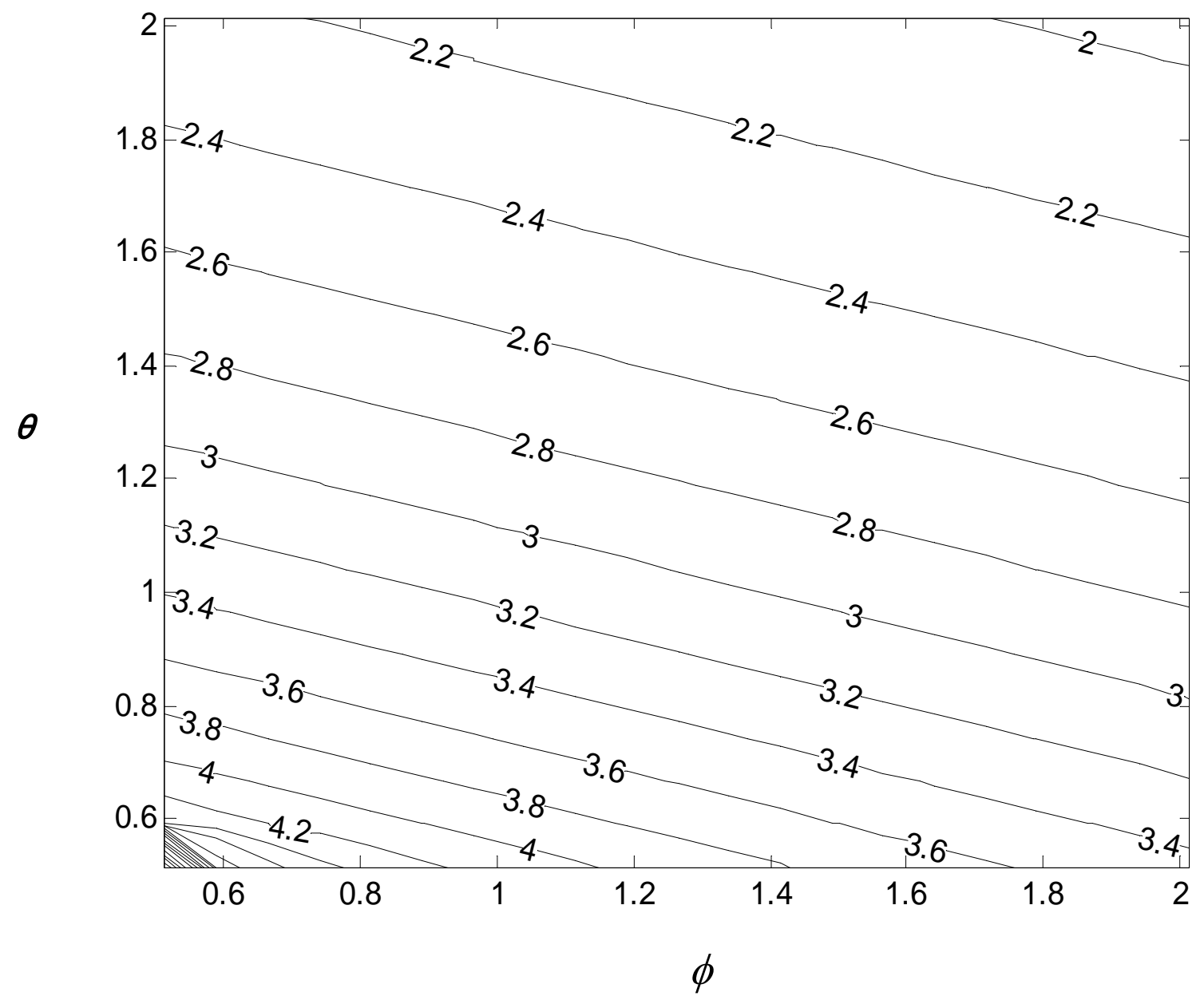

NOTE: Statistics are based on logged and HP-filtered variables. The standard deviation of the real exchange rate is divided by the standard deviation of Home real output. 